Chahayu Astina: Analisis Persaingan Ritel Lokal dan Nasional

\title{
ANALISIS PERSAINGAN RITEL LOKAL DAN NASIONAL SECARA SOSIAL-EKONOMI DI KOTA LANGSA
}

\author{
Chahayu Astina \\ Institut Agama Islam Negeri Langsa \\ E-mail: chahayu.astina@iainlangsa.ac.id
}

\begin{abstract}
Abstrak
Sebagai kota yang baru berkembang, Kota Langsa merupakan salah satu wilayah yang tepat untuk berusaha. Memperkenalkan diri sebagai Kota Jasa, Kota Langsapun berusaha untuk memenuhi kebutuhan masyarakatnya. Akan tetapi karena Kota Langsa minim industri, apalagi industri skala menengah dan sedang maka hanya kebutuhan yang bersifat konsumtif saja yang dapat dipenuhi. Oleh sebab itu, perdagangan adalah usaha yang berkembang khususnya pada usaha ritel. Sayangnya, usaha ritel masyarakat dalam beberapa tahun terakhir mengalami penurunan omset, penyebab utama adalah ketidakmampuan bisnis ritel lokal bersaing dengan ritel nasional. Oleh sebab itu tujuan penelitian ini adalah untuk menganalisis Persaingan bisnis ritel lokal nasional secara sosial-ekonomi di Kota Langsa. Dengan menggunakan pendekatan kualitatif, didapat hasil bahwa berjalannya usaha ritel nasional di Kota Langsa membuat omset pengusaha ritel lokal menurun rata-rata sebanyak 30 persen dan setiap tahunnya ada usaha ritel lokal yang mempunyai modal usaha kecil harus menutup usahanya. Menurunnya omset pengusaha ritel lokal juga membawa efek pada berkurangnya jumlah zakat yang disalurkan, berkurangnya sumbangan-sumbangan sosial lainnya seperti sumbangan untuk pembangunan mesjid, dayah, dan fakir-miskin di samping jumlah pajak yang juga ikut menurun. Sedangkan pada usaha ritel nasional efek positif yang didapat adalah dari sumbangan pajak. Besar harapan para pengusaha ritel lokal kepada pemerintah di Kota Langsa untuk lebih memprioritaskan keberlangsungan usaha lokal demi mempertahankan kestabilan perekonomian umat.
\end{abstract}

Kata kunci: Ritel, Lokal, Nasional, Sosial-Ekonomi, Langsa

\begin{abstract}
As a newly developed city, Langsa City is one of the right areas to try. Introduced as a Service City, the city strives to meet the needs of its people. However, because Langsa City has minimal in industry, especially in medium and high scale industries, only consumptive needs can be met. Therefore, trade is a growing business, especially in retail businesses. Unfortunately, community retail businesses in recent years have experienced a decline in turnover, the main cause is the inability of local retail businesses to compete with national retail. Therefore the purpose of this study was to analyze the competition of national local economic retail business in a socio-economic way in Langsa City. Using a qualitative approach, the results show that the running of the national retail business in Langsa City has made local retailers turnover decline
\end{abstract}


j-EBIS Vol. 3 No. 2 Juni 2018

by an average of 30 percent and every year there are local retail businesses that have small business capital must to shut-down their businesses. The decline in the turnover of local retailers also had an effect on the reduced amount of zakah distributed, the reduction of other social contributions such as contributions to the construction of mosques, dayah, and poor people in addition to the amount of tax that also declined. Whereas in the national retail business the positive effect obtained is from tax contributions. The expectation of local retailers to the government in Langsa City is to prioritize the sustainability of local businesses in order to maintain the stability of the people's economy.

Keywords: Retail, Local, National, Socio-Economic, Langsa

\section{PENDAHULUAN}

Era globalisasi merupakan sebuah era di mana teknologi berkembang dengan sangat cepat (moderen). Berbagai macam bentuk teknologi moderen yang baru muncul dan memperbaharui teknologi lama menjadi lebih baru memberikan utility tambahan seperti: televisi layar datar yang lebih ringan dan lebih luas layarnya untuk ditonton, peningkatan handphone menjadi smartphone, jam tangan digital yang fungsinya selain sebagai penunjuk waktu juga berfungsi untuk komunikasi dan browsing internet, jaringan internet yang semakin luas dan kencang dan sebagainya yang membuat pekerjaan semakin lebih ringan untuk diselesaikan, menambah opsi hiburan, dan akses komunikasi tanpa batas di dunia manapun.

Perkembangan teknologi tersebut sangat memudahkan manusia dalam menjalani kehidupan sehari-harinya. Bahkan kebutuhan akan teknologi telah menjadi sesuatu yang wajib dipunyai dan menjadi barang wajib bawaan ke manapun dan di manapun manusia berada. Dengan segala kemudahan-kemudahan yang ditawarkan oleh teknologi moderen tersebut ternyata membawa dampak pada gaya hidup manusia saat ini. Ingin serba mudah dan cepat (instan) telah menjadi karakter mayoritas manusia di dunia. Dalam hal pemenuhan kebutuhan sehari-hari, Manusia (konsumen) di era abad 21 ini cenderung ingin lebih mudah dan gampang dalam berbelanja. Dengan adanya demand keinginan instan tersebut, membuat pelaku bisnis berlomba-lomba dalam menawarkan jasa pada para konsumen. Sehingga bermuncul-lah bisnis-bisnis dagang dengan gedung dan desain interior yang menarik, kuantitas barang yang lengkap, dan tentunya harga yang kompeti-

tif. Hal tersebut dilakukan agar konsumen merasa nyaman, aman, dan mempermudah dalam membeli barang-barang sesuai dengan kebutuhannya. 
Chahayu Astina: Analisis Persaingan Ritel Lokal dan Nasional

Pemenuhan kebutuhan hidup sehari-hari ini dalam dunia bisnis dikenal dengan nama bisnis ritel (retail). Bisnis ritel merupakan aktivitas bisnis yang melibatkan penjualan barang dan jasa secara langsung kepada konsumen akhir. Dari hasil observasi peneliti selama 4 tahun berturut-turut (dari tahun 2014 hingga 2018), di Kota Langsa telah berdiri beberapa bisnis ritel baik itu dari pengusaha lokal maupun nasional. Mayoritas kedua jenis pengusaha tersebut menempati toko sebagai tempat bisnis. Jumlah toko yang dijadikan tempat bisnis bervariasi dari 2 hingga 4 toko agar konsumen lebih nyaman berbelanja dengan tempat yang lebih lega dan luas. Sehingga masyarakat yang ingin membeli beberapa barang dalam jumlah eceran tidak perlu susah harus berbelanja ke toko kelontong tradisional yang tempatnya lebih ramai, kurang bersih, dan akses transportasi yang berjejalan satu dengan lainnya.

Ada 2 usaha ritel lokal raksasa di Kota Langsa saat ini yaitu Sakina Swalayan dan Makmur Swalayan. Sayangnya, kedua swalayan besar tersebut belum menerapkan sistem Chain Stores, yang berarti bahwa pengusaha dari kedua bisnis ritel lokal ini belum membuka cabang-cabang usahanya (dengan memakai brand nama yang sama) dimana-mana walaupun dalam segi jumlah dan kelengkapan barang-barangnya lebih baik daripada ritel-ritel (swalayan) di sekitarnya. Selain itu, hanya Sakina Swalayan yang menerapkan strategi pemasaran dengan sistem promosi yaitu memberikan pemberitahuan potongan harga atau bonus-bonus berbelanja kepada konsumennya. Akan tetapi dari hasil observasi peneliti, strategi pemasaran dengan cara tersebut dilakukan dengan sangat sederhana sehingga tidak cukup untuk menarik perhatian konsumen. Dan belum adanya air conditioner bagi konsumen yang berbelanja sehingga mengurangi kenyamanan pada saat berbelanja dengan kondisi cuaca tropis khas Indonesia.

Dan pada saat yang bersamaan, bisnis-bisnis ritel moderen raksasa (kompetitor) juga masuk ke kota ini. Dengan permodalan yang lebih kuat membuat kompetitor lebih gampang dalam memasarkan produknya. Gerai-gerai bisnis ritel moderen ini semakin berjalannya waktu semakin tumbuh seperti jamur di musim hujan di Kota Langsa. Ada 2 (dua) bisnis ritel moderen terbesar secara nasional yang membuka gerainya yaitu Indomaret dan Alfamart. Keberadaan kedua bisnis ritel raksasa Indonesia di Kota Langsa ini menimbulkan aura kompetisi yang tajam. Tidak jarang bisa dijumpai kedua bisnis ini saling berdekatan, berdampingan, bahkan saling berhadap-hadapan.

Bukan itu saja, sebagai salah satu strategi pemasaran kedua bisnis ritel ini melakukan 
j-EBIS Vol. 3 No. 2 Juni 2018

promosi terhadap barang-barang yang dijual setiap hari sebagai salah satu upaya menarik lebih banyak konsumen untuk berbelanja. Strategi pemasaran promosi yang dilakukan lebih baik dibandingkan strategi pemasaran ritel-ritel lokal. Selain itu, walaupun barang-barang yang dijual tidak selengkap ritel lokal akan tetapi penyusunan barang-barangnya, kebersihan tempat dan kebersihan barang-barang yang dijual bebas dari debu, serta telah terpasangnya air conditoner membuat konsumen betah berlama-lama dalam berbelanja. Belum lagi pelayanannya yang ramah, aktif dalam memberikan informasi penawaran barang-barang promosi kepada konsumen tentunya meninggalkan kesan yang baik kepada konsumen sehingga membuat konsumen menjadi konsumen loyal. Konsumen yang menjadi sasaran adalah konsumen dari tingkat menengah ke bawah hingga atas.

Pada akhirnya dikhawatirkan akan terjadi persaingan bisnis yang tidak sehat. Hukum rimba akan berlaku, siapa yang kuat maka dia yang akan menang. Jika ditilik dari segi pemodalan bisnis, tentu saja bisnis-bisnis ritel lokal mempunyai modal yang lebih rendah dari bisnis ritel Indomaret dan Alfamart. Dalam prinsip ekonomi, semakin banyak modal bisnis yang dimiliki maka akan semakin banyak pendapatan yang diperoleh. Sehingga dengan menjamurnya bisnis-bisnis ritel raksasa ini di Kota Langsa, tentu saja mengganggu pendapatan bisnis ritel lokal. Apalagi jika disandingkan dengan warung-warung kecil maka tentu saja tidak menutup kemungkinan jika suatu hari nanti Kota Langsa akan menjadi kota yang bebas warung.

Sehingga dapat dirumuskan masalah dalam penelitian ini adalah bagaimana efek persaingan antara bisnis lokal dan nasional secara sosial-ekonomi di Kota Langsa?

\section{KERANGKA TEORI}

\section{Ritel}

Menurut Asosiasi Pengusaha Ritel Indonesia (APRINDO), bisnis ritel atau usaha eceran di Indonesia mulai berkembang pada kisaran tahun 1980-an seiring dengan mulai dikembangkannya perekonomian Indonesia. Hal ini timbul sebagai akibat dari pertumbuhan yang terjadi pada masyarakat kelas menengah, yang menyebabkan timbulnya permintaan terhadap supermarket dan departement store (convenience store) di wilayah perkotaan. Trend inilah yang kemudian diperkirakan akan berlanjut di masa-masa yang akan datang. Hal lain yang mendorong perkembangan bisnis ritel di Indonesia adalah adanya perubahan gaya hidup masyarakat kelas menengah ke atas, terutama di kawasan perko- 
Chahayu Astina: Analisis Persaingan Ritel Lokal dan Nasional

taan yang cenderung lebih memilih berbelanja di pusat perbelanjaan modern. Perubahan pola belanja yang terjadi pada masyarakat perkotaan tidak hanya untuk memenuhi kebutuhan berbelanja saja namun juga sekedar jalan-jalan dan mencari hiburan. Berkembangnya usaha di industri ritel ini juga diikuti dengan persaingan yang semakin ketat antara sejumlah peritel baik lokal maupun peritel asing yang marak bermunculan di Indonesia (Soliha, 2008).

Penggolongan bisnis ritel di Indonesia dapat dikategorikan berdasarkan sifatnya, yaitu ritel yang bersifat tradisional atau konvensional dan yang bersifat modern. Ritel yang bersifat tradisional adalah sejumlah pengecer atau pedagang eceran yang berukuran kecil dan sederhana, misalnya toko-toko kelontong, pengecer atau pedagang eceran yang berada di pinggir jalan, pedagang eceran yang berada di pasar tradisional, dan lain sebagainya. Kelompok bisnis ritel ini memiliki modal yang sedikit dengan fasilitas yang sederhana.

Ritel modern adalah sejumlah pedagang eceran atau pengecer berukuran besar, misalnya dengan jumlah gerai yang cukup banyak dan memiliki fasilitas toko yang sangat lengkap dan modern. Ritel modern pertama kali hadir di Indonesia saat Toserba Sarinah didirikan pada 1962. Pada era 1970 - 1980-an, format bisnis ini terus berkembang. Awal dekade 1990-an merupakan tonggak sejarah masuknya ritel asing di Indonesia. Ini ditandai dengan beroperasinya ritel terbesar Jepang 'Sogo' di Indonesia. Ritel modern kemudian berkembang begitu pesat saat pemerintah, berdasarkan Kepres no. 99 th 1998, mengeluarkan bisnis ritel dari negative list bagi Penanaman Modal Asing. Sebelum Kepres 99 th 1998 diterbitkan, jumlah peritel asing di Indonesia sangat dibatasi. Hasil survey menurut AC Nielsen lima pengecer terbesar yang termasuk dalam kategori ritel modern di Indonesia berdasarkan nilai penjualan adalah Matahari, Ramayana, Makro, Carrefour, dan Hero. Konsep yang ditawarkan peritel modern beragam seperti supermarket (swalayan), hypermarket, minimarket, departement store, dan lain sebagainya (Soliha, 2008).

\section{Sosial Ekonomi}

Pengertian Sosial Ekonomi menurut Kamus Besar Bahasa Indonesia, kata sosial berarti berkenaan dengan masyarakat. Menurut Santrock, status sosial ekonomi sebagai pengelompokan orang-orang berdasarkan kesamaan karakteristik pekerjaan dan pendidikan ekonomi.

Status sosial ekonomi menunjukan ketidaksetaraan tertentu. Secara umum anggota 
j-EBIS Vol. 3 No. 2 Juni 2018

masyarakat memiliki: (Santrock)

1. Pekerjaan yang bervariasi prestisenya, dan beberapa individu memiliki akses yang lebih besar terhadap pekerjaan berstatus lebih tinggi dibanding orang lain;

2. Tingkat pendidikan yang berbeda, ada beberapa individu memiliki akses yang lebih besar terhadap pendidikan yang baik dibanding orang lain;

3. Sumber daya ekonomi yang berbeda;

4. Tingkat kekuasaan untuk mempengaruhi institusi masyarakat. Perbedaan dalam kemampuan mengontrol sumber daya dan berpartisipasi dalam ganjaran masyarakat menghasilkan kesempatan yang tidak setara.

Soekanto memiliki ukuran atau kriteria dalam menggolongkan anggota masyarakat dalam suatu lapisan sosial, kriteria tersebut diantaranya ukuran kekayaan, ukuran kekuasaan, ukuran kehormatan dan ukuran ilmu pengetahuan. Namun, status sosial ekonomi masyarakat juga dapat dilihat dari beberapa faktor seperti:

a) Pekerjaan, pekerjaan akan menentukan status sosial ekonomi karena dari bekerja segala kebutuhan akan dapat terpenuhi. Pekerjaan tidak hanya mempunyai nilai ekonomi namun usaha manusia untuk mendapatkan kepuasan dan mendapatkan imbalan atau upah, berupa barang dan jasa akan terpenuhi kebutuhan hidupnya. Pekerjaan seseorang akan mempengaruhi kemampuan ekonominya sehingga suati keharusan bagi setiap individu dalam bekerja karena mengandung dua hal yaitu kepuasana jasmani dan terpenuhinya kebutuhan hidup. Soeroto memberikan definisi pekerjaan adalah kegiatan yang menghasilkan barang dan jasa bagi diri sendiri atau orang lain, baik orang melakukan dibayar atau tidak. Ditinjau dari segi sosial, tujuan bekerja berfungsi juga untuk mendapatkan status, untuk diterima menjadi bagian dari satu unit status sosial ekonomi dan untuk memainkan suatu peranan dalam statusnya. dalam pedoman ISCO (International Standart Clasification of Occupation) pekerjaan diklasifikasikan sebagai berikut:

Profesional ahli teknik dan ahli jenis.

1) Kepemimpinan dan ketatalaksanaan.

2) Administrasi tata usaha dan sejenisnya

3) Jasa 
4) Petani

5) Produksi dan operator alat angkut

b) Pendidikan, pendidikan berperan penting dalam kehidupan manusia karena mempunyai manfaat untuk seumur hidupnya. Dengan pendidikan, diharapkan seseorang dapat membuka pikiran untuk menerima hal-hal baru serta berpikir secara alamiah untuk kelangsungan hidup dan kesejahteraan dirinya, masyarakat dan tanah airnya.

c) Pendapatan, Christopher dalam Sumardi mendefiniskan pendapatan berdasarkan kamus ekonomi adalah uang yang diterima oleh seseorang dalam bentuk gaji, upah sewa, bunga, laba dan lain sebagainya. Biro Pusat Statistik (BPS) merinci pendapatan dalam kategori sebagai berikut:

(1) Pendapatan berupa uang adalah segala penghasilan berupa uang yang sifatnya regular dan diterima biasanya sebagai balas atau kontra prestasi yang sumbernya bisa berasal dari: i) Gaji dan upah yang diterima dari gaji pokok, kerja sampingan, kerja lembur dan kerja kadang-kadang; ii) usaha sendiri yang meliputi hasil bersih dari usaha sendiri, komisi, penjualan dari kerajinan rumah; iii) hasil investasi yaitu pendapatan yang diperoleh dari hak milik tanah. Keuntungan serial yakni pendapatan yang diperoleh dari hak milik.

(2) Pendapatan berupa barang yaitu, pembayarn upah dan gaji yang ditentukan dalam beras, pengobatan, transportasi, perumahan dan kreasi.

\section{METODE}

Metode yang digunakan dalam penelitian ini adalah metode kualitatif. Metode penelitian kualitatif merupakan metode penelitian yang lebih menekankan pada aspek pemahaman secara mendalam terhadap suatu masalah dari pada melihat permasalahan untuk penelitian generalisasi. Metode penelitian ini lebih suka menggunakan teknik analisis mendalam (in-depth analysis), yaitu mengkaji masalah secara kasus perkasus karena metodologi kulitatif yakin bahwa sifat suatu masalah satu akan berbeda dengan sifat dari masalah lainnya (Afrizal, 2016).

Lokasi penelitian berada di Kota Langsa yaitu outlet-outlet swalayan atau market punya pengusaha lokal. Peneliti memilih Kota Langsa sebagai tempat penelitian karena masalah yang peneliti temukan adalah di Kota Langsa yaitu permasalahan sustainability perekono- 
j-EBIS Vol. 3 No. 2 Juni 2018

mian pengusaha lokal semenjak masuknya ritel nasional (Alfamart dan Indomaret) ke Kota Langsa.

Sampel yang diambil berkategori nonprobability sampling yaitu tidak setiap individu yang terdapat dalam populasi dapat dijadikan sampel, jenisnya purposive sampling yaitu metode penetapan responden untuk dijadikan sampel berdasarkan kriteria-kriteria tertentu (Siregar, 2014).

Dalam penelitian ini metode pengumpulan data dilakukan dengan berbagai teknik. Untuk data primer metode peengumpulan data yang dilakukan berupa:

1. Observasi, yaitu kegiatan pemuatan penelitian terhadap suatu objek. Apabila dilihat pada proses pelaksanaan pengumpulan data, observasi dibedakan menjadi partisipan dan non-partisipan. Jenis observasi yang digunakan pada penelitian ini adalah observasi non-partisipan. Dalam melakukan observasi, peneliti memilih halhal yang diamati dan mencatat hal-hal yang berkaitan dengan penelitian.

2. Wawancara, Teknik wawancara dalam penelitian ini menggunakan teknik wawancara bebas terpimpin. Arikunto menjelaskan bahwa wawancara bebas terpimpin adalah wawancara yang dilakukan dengan mengajukan pertanyaan secara bebas namun masih tetap berada pada pedoman wawancara yang sudah dibuat. Pertanyaan akan berkembang pada saat melakukan wawancara. Peneliti mendapatkan informasi langsung dengan teknik wawancara dari pemerintahan (Dinas Perindustrian dan Perdagangan), ulama dan para pengusah outlet dan swalayan (mart).

3. Dokumentasi, menurut Sugiyono (2015) adalah suatu cara yang digunakan untuk memperoleh data dan informasi dalam bentuk buku, arsip, dokumen, tulisan angka dan gambar yang berupa laporan serta keterangan yang dapat mendukung penelitian. Dokumentasi digunakan untuk mengumpulkan data kemudian ditelaah. Dokumentasi yang digunakan dalam penelitian ini meliputi foto-foto penelitian, dan survey.

Analisis data adalah upaya yang dilakukan dengan jalan bekerja dengan data, mengorganisasikan data, memilah-milahnya menjadi satuan yang dapat dikelola, mensintesiskannya, mencari dan menemukan pola, menemukan apa yang penting dan apa yang dipelajari, dan memutuskan apa yang dapat diceriterakan pada orang lain. 
Chahayu Astina: Analisis Persaingan Ritel Lokal dan Nasional

Miles \& Huberman (2014: 17) menyebutkan bahwa teknik analisis data dalam peneltian kualitatif meliputi :

1. Pengumpulan Data, Mengolah dan mempersiapkan data untuk dianalisis. Langkah ini melibatkan transkrip wawancara, men-scanning materi, mengetik data lapangan atau memilah-milah dan menyusun data tersebut ke dalam jenis-jenis yang berbeda tergantung pada sumber informasi.

2. Reduksi data (Data Reduction), Reduksi data merupakan suatu bentuk analisis yang menggolongkan, mengarahkan, membuang yang tak perlu dan mengorganisasikan data-data yang telah di reduksi memberikan gambaran yang lebih tajam tentang hasil pengamatan menjadi tema.

3. Penyajian Data (Data Display) Penyajian data merupakan analisis dalam bentuk matrik, network, cart, atau grafis. Pada penelitian kualitatif, penyajian data dilakukan dalam bentuk uraian singkat, tabel, bagan dan hubungan antar kategori. Melalui penyajian data tersebut, maka data terorganisasikan, dan tersusun sehingga akan semakin mudah dipahami.

4. Penarikan Kesimpulan (Conclusion Drawing/Verivication) Kesimpulan merupakan penarikan kesimpulan dan verifikasi. Kesimpulan awal yang dikemukakan masih bersifat sementara, dan akan berubah apabila tidak ditemukan bukti-bukti kuat yang mendukung tahap pengumpulan berikutnya. Kesimpulan dalam penelitian kualitatif dapat menjawab rumusan masalah yang dirumuskan sejak awal.

\section{PEMBAHASAN}

Kota Langsa terbentuk melalui Undang-Undang Nomor 3 Tahun 2001 yang sebelumnya berstatus kota administratif menjadi Pemerintah Kota. Kota Langsa terletak di sebelah Timur Provinsi Aceh, yang berposisikan sebelah Utara Pulau Sumatera, yaitu pada $04^{\circ} 24^{\prime} 35,68^{\prime \prime}-04^{\circ} 33^{\prime} 47,03^{\prime \prime}$ Lintang Utara dan $97^{\circ} 53^{\prime} 14,59^{\prime \prime}-98^{\circ} 04^{\prime} 42,16^{\prime \prime}$ Bujur Timur, dan memiliki luas wilayah $262,41 \mathrm{Km}^{2}$.

Kota Langsa terletak pada daratan aluviasi pantai dengan elevasi berkisar $8 \mathrm{~m}$ dari permukaan laut, di bagian Barat Daya dan Selatan dibatasi oleh pegunungan lipatan bergelombang sedang, dengan elevasi berkisar $75 \mathrm{~m}$, sedangkan pada bagian Timur merupakan endapan rawa-rawa dengan penyebaran cukup luas. Kota Langsa juga mempunyai da- 
j-EBIS Vol. 3 No. 2 Juni 2018

ratan rendah dan bergelombang, sungai-sungai dengan iklim basah, curah hujan rata-rata berkisar $1.850-4.013 \mathrm{~mm}$ pertahun dengan suhu udara antara $28^{\circ} \mathrm{C}-30^{\circ} \mathrm{C}$. Wilayah Kota Langsa berada pada ketinggian 0-25 m dari permukaan laut (Badan Pusat Statistik dalam BAPPEDA Kota Langsa, 2012)

Jumlah Penduduk Kota Langsa 162.814 jiwa pada tahun 2015. Dimana jumlah penduduk berjenis kelamin wanita 82.182 jiwa sedang jenis kelami pria 80.632 jiwa. Penduduk berjenis kelamin wanita lebih banyak sedikit dibanding pria hanya berselisih 1550 jiwa lebih banyak wanita. Jumlah penduduk wanita lebih banyak dibandingkan dengan penduduk wanita bisa saja mungkin banyak pria merantau keluar daerah atau keluar negeri. komposisi penduduk wanita lebih banyak memberikan gambaran tersendiri mengenai kondisi penduduk Kota Langsa. Perlu juga diamati mengenai dampak dampak lain yang ditimbulkan oleh kondisi lebih banyak perempuan ini. Populasi penduduk yang terpadat yaitu di Kecamatan Langsa baro bermukim 46.622 jiwa sedangkan yang paling jarang penduduk kecamatan Langsa Timur 15.123 jiwa. Penduduk kota langsa sudah diatas 50.000 jiwa artinya langsa sudah dapat dikatagorikan sebagai kota sedang (BPS Kota Langsa, 2015).

Mayoritas penduduk Kota Langsa adalah suku Aceh, suku Melayu, suku Jawa, suku Tionghoa, dan suku Batak. Bahasa Aceh digunakan oleh mayoritas masyarakat Kota Langsa, namun bahasa Indonesia tetap menjadi bahasa utama. Agama Islam adalah agama mayoritas masyarakat Kota Langsa dan rakyat Aceh umumnya. Hukum Syariat Islam menjadi aturan dasar dalam kehidupan masyarakat Kota Langsa. Agama Kristen juga menjadi bagian dari populasi, sementara Buddha banyak diadopsi oleh komunitas warga Tionghoa (China). Kota Langsa merupakan kota yang kaya akan perbedaan etnis dan penduduk tetap hidup dalam damai serta memiliki toleransi beragama yang kuat. Lokasi Kota Langsa sangat dekat dengan Medan, ibu kota Provinsi Sumatera Utara, sehingga menempatkan Kota Langsa sebagai kota yang strategis dan ramai imigran.

Sejak terbentuk secara definitif pada tahun 2001, Pemerintah Kota Langsa terus berupaya melaksanakan pembangunan demi terwujudnya kesejahteraan masyarakat. Disamping hasil pembangunan yang telah dicapai, baik yang terkait dengan urusan wajib maupun pilihan yang diemban Pemerintah Kota dalam melaksanakan pembangunan, dijumpai pula beberapa permasalahan pembangunan yang harus diatasi dan dituntaskan dalam jangka menengah ke depan (periode 2012-2017). 
Chahayu Astina: Analisis Persaingan Ritel Lokal dan Nasional

Permasalahan tersebut akan diatasi secara terpadu, komprehensif, dan tepat, mengingat dampaknya berpotensi begitu besar menghambat kemajuan pembangunan kota. Inti permasalahan tersebut terjadi pada umumnya akibat terbatasnya kemampuan anggaran pemerintah, kurangnya sarana dan prasarana pendukung, dan relatif rendahnya kualitas sumberdaya manusia.

Laju pertumbuhan ekonomi kota sepanjang tahun 2007-2015 masih cenderung tumbuh lambat dari pertumbuhan ekonomi nasional, meskipun terus bergerak naik dalam dua tahun terakhir. Dalam kurun waktu tersebut, pertumbuhan ekonomi kota juga menunjukkan fluktuasi. Kondisi tersebut mengindikasikan pondasi ekonomi Kota Langsa masih rawan dari berbagai gejolak dan goncangan ekonomi, baik dipicu secara internal maupun eksternal. Akhir tahun 2009, tercatat pertumbuhan ekonomi kota sebesar 4,32 persen, jauh lebih rendah dari pertumbuhan ekonomi nasional sebesar 6,95 persen dan provinsi sebesar 5,89 persen. Berikut tabel jumlah dan persentasae penduduk miskin Kota Langsa dari tahun 2007-2015.

Masih rendahnya pertumbuhan ekonomi kota berkait erat dari berbagai permasalahan dan tantangan yang dihadapi Pemerintah Kota dalam upaya mewujudkan pertumbuhan ekonomi yang tinggi dan berkualitas. Pengelolaan antara lain, berupa masih terbatasnya investasi swasta, minimnya anggaran yang diimplementasikan untuk sektor-sektor produktif, belum optimalnya pendayagunaan sumberdaya ekonomi lokal, dan belum optimalnya pemanfaatan pelabuhan Kuala Langsa. Karena itu, diperlukan kebijakan yang lebih tepat dan terarah guna meningkatkan laju pertumbuhan ekonomi berkualitas dalam jangka menengah ke depan. Kebijakan yang dapat mendorong minat para calon investor untuk menanamkan modalnya di kota adalah salah satu upaya yang sangat penting untuk dilaksanakan, disamping pula upaya keras mendorong meningkatkan kapasitas UMKM dan optimalisasi pendayagunaan pelabuhan Kuala Langsa dalam mendukung aktivitas perdagangan dan perluasan penyerapan tenaga kerja.

Kedudukan Kota Langsa yang berada di jalan lintas nasional di wilayah pantai Timur Aceh, merupakan suatu nilai strategis sebagai potensi sekaligus peluang yang perlu dimanfaatkan secara optimal. Dalam posisi tersebut, Kota Langsa semestinya dapat menjadi pusat pertumbuhan ekonomi terbesar di wilaya Pantai Timur Aceh dengan memanfaatkan peluang strategis dari keberadaan daerah hiterland di sekitarnya, terutama Kabupaten Aceh Timur dan Aceh Tamiang (Samsuar, 2016). 
j-EBIS Vol. 3 No. 2 Juni 2018

Berdasarkan data BPS, tahun 2014 perekonomian Kota Langsa sebesar 4,23 persen. Kondisi pertumbuhan ekonomi kota di pengaruhi dari kontribusi sektor perdagangan besar dan eceran dimana sektor ini yang paling mendominasi dalam struktur ekonomi kota Langsa yaitu sebesar 19,02 persen. Potensi lain dapat di analisis bahwa sektor tersebut dapat beraviliasi dengan sektor lainnya seperti industri pengolahan yang turut menyumbang andil terhadap pertumbuhan ekonomi.

Seperti yang telah dipaparkan sebelumnya bahwa pertumbuhan ekonomi di Kota Langsa banyak dipengaruhi oleh sektor perdagangan baik itu perdagangan besar maupun eceran. Menurut pengamatan peneliti, alasan sektor perdagangan mendominasi pertumbuhan di Kota Langsa karena kurang hidupnya sektor-sektor swasta dan mandiri lainnya seperti industri terasi dan kecap asin yang terkenal di Kota Langsa tapi masih dalam skala home industry. Artinya dalam memproduksi hasil masih terbatas dalam jumlah, pemasaran dan penyerapan tenaga kerja.

Minimnya sektor swasta yang berkembang di Kota Langsa, membuat para angkatan kerja berharap besar pada pekerjaan sebagai Pegawai Negeri Sipil (PNS). Oleh sebab itu, sektor perdaganganlah yang menghidupkan perekonomian Kota Langsa selam satu dekade ini. Dalam beberapa tahun terakhir, khususnya selama rentang waktu 3-4 tahun belakangan ini, ritel lokal tidak hanya bersaing dengan sesama ritel lokal saja tetapi juga bersaing dengan ritel moderen.

Selama kurang lebih 4 tahun peneliti mengobservasi kondisi perdagangan di Kota Langsa, peneliti menemukan bahwa sebagai kota yang sedang berkembang, kondisi ritel yang ada di Kota Langsapun beragam. Mulai dari kios hingga minimarket/swalayan telah banyak tumbuh dari pusat kota hingga dekat ke perumahan penduduk. Pembeli yang berbelanja pun selalu ramai. Akan tetapi setelah masuknya Indomaret dan Alfamart yang mendirikan usahanya di setiap sudut Kota Langsa, peneliti meyakini dan merasakan sendiri ketika berbelanja di ritel swalayan lokal pembeli yang berbelanja tidak ramai seperti dulu. Berkurangnya pembeli yang berbelanja di ritel swalayan lokal, menurut analisis peneliti akan memberikan efek negatif bagi keberlangsungan kesejahteraan di Kota ini. Karena seperti yang telah disebutkan bahwa hanya sektor perdaganganlah yang menjadi sektor swasta dan mandiri yang mempunyai andil utama dalam pertumbuhan perekonomian Kota Langsa. 
Chahayu Astina: Analisis Persaingan Ritel Lokal dan Nasional

Untuk mendapatkan hasil analisis dari berbagai kalangan, maka peneliti melakukan Focus Group Discussion (FGD) yang dilaksanakan pada Selasa, 21 Agustus 2018 bertempat di WRH Caffe Langsa. Dengan menghadirkan narasumber dari Dinas Perindustrian dan Perdagangan dan dari pihak ulama.

Adapun hasil pemaparan dari Dinas Perindustrian dan Perdagangan adalah Kota Langsa adalah Kota Jasa, sehingga pemberian izin kepada Indomaret dan Alfamart dilakukan untuk menambah Pendapatan Asli Daerah. Pemberian izin tersebut melalui proses panjang, karena sebelumnya pemerintah kota sempat menahan pemebarian izin tersebut. Secara pribadi, sosialisasi kepada masyarakat dilakukan seperti saran agar berbelanja di ritel lokal sendiri. Sebelum pemerintah kota sekarang, Indomaret telah lahir terlebih dahulu semenjak di bawah tahun 2010-2011. Belakangan beberapa tiga tahun belakang baru Alfamart masuk. Pemberian izin tidak semata-mata diberikan oleh pemerintah kota (walikota) tetapi juga atas rekomendasi dan kebijakan dari beberapa dinas-dinas terkait. KP2T tidak akan memberi izin jika tidak ada rekomendasi dari dinas. Dengan pertimbangan Langsa adalah Kota Jasa sehingga apabila ada investor-investor masuk yang ditahan akan memberi efek negatif bagi Kota Langsa. Walaupun menurut pribadi pak Muhsin sendiri kehadiran Indomaret dan Alfamart memberikan efek negatif khususnya bagi toko-toko pengecer kecil lainnya.

Tetapi menurut pihak Dinas Perindustrian dan Perdagangan Kota Langsa, menurunnya omset pedagang ritel lainnya bukan hanya disebabkan karena masuknya ritel nasional ini tetapi juga karena keadaan perekonomian secara keseluruhan yang lagi menurun bukan hanya Kota Langsa yang mengalami pelesuan tetapi juga daerah-derah lain. Sebagai Kota Jasa dan tempat pusat perputaran uang dari Aceh Timur dan Aceh Tamiang, maka Kota Langsa harus menyediakan sarana dan prasarana yang memadai termasuk tempat berbelanja agar pilihan masyarakat semakin beragam.

Sedangkan untuk pengurusan izin bagi swalayan lokal juga harus melakukan pengurusan izin dengan diawali oleh pemberian rekomendasi menerima atau menolak, maka KP2Tlah yang akan melakukan riset kelayakan tersebut dan memberikan hasilnya.

Sedangkan menurut salah satu ulama yang menjadi narasumber pada acara FGD peneliti, beliau menolak masuk dan beroperasinya ritel Indomaret dan Alfamart di Kota Langsa. Karena selain yang punya usaha tersebut bukan penduduk Kota Langsa dan non-muslim, 
j-EBIS Vol. 3 No. 2 Juni 2018

masalah persaingan yang tidak adil dari segip pemodalan dan manajemen akan membangkrutkan pengusaha-pengusaha ritel swalayan lokal. Apalagi yang masuk bukan dalam jumlah sedikit tetapi sudah dalam kuantitas yang sangat banyak karena setiap mata memandang di Kota Langsa, maka Indomaret dan Alfamart akan ada dimana-mana. Jika diteruskan maka Maqashid Syariah di Kota Langsa lambat laun tidak akan terwujud.

Pada saat peneliti melakukan pengumpulan data dari para pengusaha ritel lokal yang berjumlah 12 orang, peneliti juga melakukan pengumpulan data dengan teknik wawancara. Para responden tetap dijaga kerahasiaannya dengan menggunakan nama singkatan usaha ritelnya. Adapun beberapa hasil wawancara yang didapat oleh peneliti dimulai dari: Pengusaha ritel swalayan MM yang berlokasi di dekat wilayah kampus IAIN Langsa menyatakan bahwa tidak ada persaingan berarti bagi masuknya ritel Indomaret dan Alfamart ke Kota Langsa. Walaupun jumlahnya sekarang sudah tidak terhitung jari lagi, namun dengan strategi harga yang kompetitif yang ditawarkan pada usahanya beliau optimis usahanya akan tetap lancar. Karena harga yang ditawarkan oleh kedua ritel nasional itu sebenarnya lebih mahal, sehingga pembeli yang jeli pasti akan sadar dan tetap setia menjadi pelanggannya. Walaupun begitu, pernah ada usaha yang telah dilakukan oleh Pengusaha MM untuk membendung arus masuknya ritel-ritel nasional tersebut seperti membentuk sebuah komunitas. Dan sebagai ketua komunitas usaha outlet di Kota Langsa, aspirasi dari anggota untuk membatasi bahkan tidak memberikan izin bagi masuknya ritel-ritel nasional itu telah dilakukan dengan menyuarakannya langsung ke anggota dewan derah (DPRD) dan pemerintah Kota Langsa. Akan tetapi keinginan tersebut sampai sekarang tidak ada tanggapan apalagi perubahan kebijakan. Hal ini ditengarai oleh kemungkinan adanya pihak-pihak yang berkepentingan terhadap masuknya ritel nasional dan pihak tersebut adalah kaum kuat baik dari segi pemodalan maupun kedekatan dengan pemerintah dan anggota dewan sehingga upaya untuk diperhatikan keberlangsungan usaha ritel lokal menjadi sia-sia.

Pengusaha ritel swalayan AM yang berlokasi di daerah pemukiman gampong Jawa mengatakan bahwa usahanya menjadi lebih susah berkembang dan memperoleh omset yang banyak karena ritel nasional ini sendiri gampang untuk dijumpai. Dengan tempat yang lebih nyaman karena memiliki air conditioner (AC) maka pembeli lebih tertarik untuk membeli barang di Indomaret atau Alfamart. Akan tetapi karena sudah terlanjur mengeluarkan modal yang tidak sedikit, maka suka atau tidak suka dengan kehadiran ritel nasional itu, Pengusaha swalayan AM tetap mempertahankan usahanya. Kelemahan dalam 
Chahayu Astina: Analisis Persaingan Ritel Lokal dan Nasional

hal pelayanan, jumlah karyawan dan modal yang tidak mungkin menang dalam bersaing dengan ritel nasional menjadi sebuah ancaman bagi keberlangsungan usahanya.

Menurut pengusaha swalayan MS yang berlokasi di daerah TM. Zein mengatakan bahwa pemerintah seperti tidak perduli terhadap nasib pengusaha pedagang ritel lokal. Omset dari usaha ibu MS setiap tahun semakin menurun. Terbukti dari omset zakat yang bisa dikeluarkan sebelum adanya ritel nasional di Kota Langsa sebesar Rp 100 juta menjadi Rp 60 juta - Rp 70 juta setahun. Selain itu kesulitan dalam biaya usaha yang semakin lama harus ditekan pengeluarannya agar harga yang dijual bisa sama bahkan lebih murah dari ritel nasional dilakukan. Dalam segi pemasokan barang, usaha ritel ibu MS mendapatkannya dari distributor atau tangan kedua sedangakan ritel nasional bisa mendapatkan barang langsung dari pabrik karena jumlah pengambilan barang yang berkali lipat banyaknya dibanding ritel lokal.

Dari segi sosial, usaha-usaha ritel yang berdiri di Kota Langsa telah banyak membantu berdirinya dayah-dayah dan penggerak kegiatan-kegiatan mesjid dari sumbangan yang berbentuk kotak amal yang biasa dijumpai pada usaha ritel lokal. Permasalahan ini pernah beberapa kali disampaikan pada salah satu tokoh yang dianggap ulama dan dianggap juga dekat ke walikota, tetapi belum pernah ada balasan. Jika alasan pemerintah bisa mendapatkan pendapatan lebih banyak dari pajak usaha ritel nasional itu, maka ritel lokalpun taat pajak. Bukan hanya taat pajak tetapi juga taat zakat. Selain itu sumbangan dari pembeli dirasakan langsung oleh pihak yang disantuni, sedangkan ritel nasional sumbangan pembeli tidak dapat dirasakan langsung oleh pihak-pihak yang membutuhkan di daerah tersebut karena prosedurnya setiap sumbangan harus ditransfer dulu ke pusat baru didistribusikan ke pihak yang membutuhkan ke seluruh daerah di Indonesia.

Masuknya swalayan Suzuya semakin menambah berat persaingan yang dianggap tidak seimbang oleh bu MS. Karena jika dibandingkan modal, sistem manajemen dan pelayanan prima ritel lokal yang masih di bawah ritel nasional, maka tidak menutup kemungkinan suatu hari usahanya akan bankrut. Dan yang disesalkan adalah pemerintah seakan-akan tidak perduli dengan nasib para ritel lokal yang setiap tahun selalu mengalami penurunan, padahal dari sektor inilah satu-satunya sektor swasta dan mandiri di Kota Langsa yang masih bertahan dan mempertahankan kondisi perekonomian kota Langsa. 
j-EBIS Vol. 3 No. 2 Juni 2018

\section{SIMPULAN}

Dari hasil penelitian dapat disimpulkan bahwa secara sosial ekonomi dengan masuknya ritel nasional terbesar di Indonesia yaitu Indomaret dan Alfamart membawa dua efek yaitu positif dan negatif. Dari segi positifnya, peneliti mendapat hasil bahwa dengan masuknya ritel nasional menyerap tenaga kerja dengan gaji yang kompetitif. Selain itu pemerintah kota juga mendapatkan hasil berupa pemasukan pajak yang terbilang tinggi walaupun jumlah pasti pajak ini belum peneliti ketahui dari narasumber penelitian ini. Dalam segi kompetisi pada bidang bisnis, ritel nasional membawa suatu pembaharuan dalam hal manajemen usaha dan pelayanan pembeli (konsumen). Dengan interior dan fasilitas yang lebih baik, membuat para pembeli betah untuk berlama-lama berbelanja dan tidak menutup kemungkinan untuk kembali berbelanja lagi.

Dari segi negatif, masuknya ritel nasional dengan seluruh fasilitas terbaiknya membuat pembeli bisnis ritel lokal beralih. Hal ini mengakibatkan turunnya omset usaha yang tidak sedikit yaitu rata-rata 30 persen. Penurunan omset tersebut diikuti dengan penurunan jumlah pajak yang disetor kepada pemerintah kota, menurunnya jumlah zakat yang disalurkan, menurunnya sumbangan-sumbangan yang diberikan kepada mesjid terdekat, dayah dan fakir-miskin. Selain itu durasi jam buka usaha yang lebih lama diberlakukan oleh sebagian usaha ritel lokal untuk meningkatkan kembali pendapatannya, tetapi usaha tersebutpun tidak memperoleh hasil yang baik.

Selain itu, gaji yang diberikan oleh ritel lokal terhadap karyawannya ternyata tidaklah utuh. Para karyawan harus bertanggung jawab terhadap selisih harga dan kekurangan-kekurangan lain pada saat melakukan transaksi dengan pemotongan gaji setiap bulannya. Sehingga gaji yang diterima karyawan selalu berkurang 20-40 persen setiap bulannya.

Adapun terhadap masalah-masalah yang dihadapi para ritel lokal selama bertahun-tahun ini telah dilakukan upaya dan usaha untuk menyuarakannya kepada pemerintah kota. Namun upaya yang dilakukan tersebut sampai saat ini belum ditanggapi atau mendapat respon yang positif.

Sehingga peneliti menyarankan agar ada upaya masif dari masyarakat kota Langsa untuk berbelanja pada usaha ritel lokal dan warung-warung selain itu sosialisasi para akademisi khususnya yang concern pada bidang sosial dan ekonomi kepada masyarakat agar lebih 
Chahayu Astina: Analisis Persaingan Ritel Lokal dan Nasional

memajukan perekonomian sendiri dan upaya agar pemerintah kota dapat lebih selektif dalam memberikan izin pada investadi dari luar yang mengancam stabilitas perekonomian khususnya perekonomian di Kota Langsa.

\section{DAFTAR PUSTAKA}

Afrizal. 2016. Metode Penelitian Kualitatif: Sebuah upaya Mendukung Pengguanaan Penelitian Kualitatif dalam Berbagai Disiplin Ilmu. Jakarta: PT. Raja Grafindo Persada, Jakarta.

Badan Pusat Statistik dalam BAPPEDA Kota Langsa, 2012

BPS Kota Langsa, 2015

Euis Soliha. 2008. Analisis Industri Ritel di Indonesia. Jurnal Bisnis dan Ekonomi (JBE). Vol. 15, No. 2. September 2008. ISSN: 1412-3126. Fakultas Ekonomi Universitas Stikubang Semarang.

Samsuar. 2016. Langsa Sebagai Pusat Perdagangan, Industri dan Jasa Kepelabuhan di Kawasan Timur Aceh. Kertas Kebijakan Vol. 2, No 1 Tahun 2016.

Huberman, dan Miles. 2014. Analisis Data Kualitatif. Jakarta: Universitas Indonesia.

Siregar, Sofyan. 2014. Statistik Parametrik Untuk Penelitian Kuantitatif. Jakarta: Bumi Aksara.

Sugiyono. 2014. Metode Penelitian Kuantitatif Kualitatitf dan R\&D. Bandung: Alfabeta. 